\title{
Clinico-Epidemological Profile of Corneal Ulcer Cases from Rural Hospital of Haryana, India
}

\author{
Kanishtha Sharma ${ }^{1}$, Dipender Kaur Najotra ${ }^{*}$ and Varsha A. Singh ${ }^{2}$ \\ ${ }^{1}$ Departmeny of Microbiology, Acharya Shri Chander College of Medical Sciences and Hospital \\ Jammu, Jammu and Kashmir, India \\ ${ }^{2}$ Department of Microbiology, Maharishi Markandeshwar Institute of Medical Sciences and \\ Research (MMIMSR), Mullana, Ambala, Haryana, India \\ *Corresponding author
}

\begin{tabular}{|c|c|}
\hline \multicolumn{2}{|r|}{ A B S T R A C T } \\
\hline & \multirow{6}{*}{$\begin{array}{l}\text { Corneal ulceration is a leading cause of ocular morbidity and blindness worldwide. India } \\
\text { being an agricultural land, corneal trauma leading to rapidly progressing corneal ulceration } \\
\text { is very common. Many studies have been published on corneal ulcers all over the country } \\
\text { but no study has been published from rural part of Haryana. Therefore this study was } \\
\text { undertaken to find the rate of bacterial and fungal isolates in corneal ulcers and to assess } \\
\text { their clinical epidemiology. The present study was carried in the Department of } \\
\text { Microbiology, MMIMSR, Haryana on } 200 \text { clinically suggested cases of corneal ulcers. } \\
\text { Corneal scrapings were subjected to microscopy and culture. Of } 200 \text { suspected cases, } \\
43.5 \% \text { were culture positive. Staphylococcus aureus and Pseudomonas aeruginosa were } \\
\text { the predominant gram positive and negative bacterial isolates. Aspergillus species was the } \\
\text { most prevalent fungal isolate. Ocular trauma and tropical steroids was the commonest } \\
\text { predisposing factor. Sugarcane leaf trauma was the commonest vegetative origin trauma. } \\
\text { Redness, blurred/diminished vision was most commonly seen in fungal keratitis while } \\
\text { pain, redness was most commonly seen in bacterial keratitis. The clinical presentations of } \\
\text { bacterial and fungal corneal ulcers are often overlapping and confirmation by } \\
\text { microbiological testing is essential for better treatment. }\end{array}$} \\
\hline Keywords & \\
\hline & \\
\hline Article Info & \\
\hline & \\
\hline & \\
\hline
\end{tabular}

\section{Introduction}

Corneal ulcer is a key cause of blindness throughout the world. India being an agricultural land, superficial corneal trauma in farming frequently leads to rapidly progressing corneal ulceration and visual loss (Srinivasan et al., 1997). Suppurative keratitis is an important cause of monocular vision loss worldwide but unfortunately the clinical features do not always correlate to the classical textbook description. Thus the consequences mislead the diagnosis, further leading to improper treatment and complications. In view of that quick and accurate identification of microorganisms entails for proper management. Many studies have been published on corneal ulcers from various parts of India (Geethakumari et al., 2011; Tewari et al., 2012 and Balagurunathan et al., 2012) but from Haryana inspire of being the agricultural hub of the country, no study has been published from the rural part of the state. 


\section{Materials and Methods}

The study was carried out on 200 clinically suggested patients of corneal ulceration attending Ophthalmology OPD and IPD of Maharishi Markandeshwar Institute of Medical Sciences and Research (Mullana, Haryana) for a period of 2 years i.e., Oct 2012-2014.

\section{Sample collection}

After a detailed clinical history, the findings of corneal ulcer were noted after a thorough slit lamp examination. The effected eye was locally anesthetized after washing with normal saline to remove all necrotic material. Scrapings from base and edges of the corneal ulcer were collected using a sterile Bard Parker blade no.15 or Kimura's Spatula and send to the Microbiology laboratory.

\section{Sample processing}

The scrapings were inoculated on Blood agar and Sabourand's dextrose agar and processed further as per the standard laboratory procedures for bacterial and fungal identification (Wilson, 1998).

\section{Results and Discussion}

Out of 200 suspected cases of bacterial and fungal keratitis, 87(43.5\%) showed growth. Of these fungal isolates were 53(60.91\%), bacterial isolates were 27(31.03\%) while $7(8.04 \%)$ showed mixed growth.

Among the bacterial isolates, gram positive cocci accounted 16(59.25\%) and gram negative bacilli 11(40.74\%). Staphylococcus aureus $11(68.75 \%)$ constituted majority of the gram positive isolates followed by Staphylococcus epidermidis 5(31.25\%). Pseudomonas aeruginosa constituted $6(54.54 \%)$ of the gram negative isolates followed by Escherichia coli 3(27.27\%) and Klebsiella pneumoniae 2(18.18\%). Among the fungal isolates, Aspergillus species was the most prevalent (43.39\%) followed by Fusarium solani, Curvularia geniculata and Candida albicans with $11.32 \%$ (Table 1).

In patients of corneal ulcer, ocular trauma was the most common predisposing factor followed by topical steroids and diabetes mellitus. Among the positive cases, ocular trauma contributes $57.4 \%$, tropical steroids $80.5 \%$ and diabetes mellitus $72.7 \%$ (Fig. 1).

There is a close association of predisposing factors with etiological agents. Ocular trauma which was the most common predisposing factor showed profound association with fungal etiology $(81.48 \%)$ as compared to it acute conjunctivitis and contact lens wearers showed association with bacterial etiology $(100 \%)$. Diabetes mellitus and topical steroids had equal association with both bacterial and fungal etiology (Table 2).

The frequency of positivity in ocular trauma cases was more due to vegetative origin $(74.07 \%)$ as compared to foreign body $(25.92 \%)$. Sugarcane leaf trauma $(52.5 \%)$ was the commonest amongst vegetative origin trauma. The commonest majority of the isolates from the vegetative origin were fungal in etiology $(91.6 \%)$.

In contrast, in trauma due to foreign body, occurrence of bacterial and fungal etiological agents was equal (Table 3 ).

Studying the demographic profile in the present study, of the 200 cases of bacterial and fungal keratitis, $56.5 \%$ were male and $43.5 \%$ were female. Maximum (51.5\%) patients were in age group 20-40 yrs and minimum $(3.5 \%)$ in age group $<20$ yrs of age. Rural and urban population accounted for $58.5 \%$ and $41.5 \%$ of the cases respectively. 
Farming (40\%) was the predominant occupation followed by housewives (23\%). Maximum number of cases were seen in the months July-Sep (38.5\%) followed by OctDec $(31 \%)$ (Table 4).

The common sign and symptoms in fungal keratitis were redness $(81.25 \%)$, blurred/diminished vision $(81.25 \%)$, pain $(68.7 \%)$ and irregular feathery margins $(75 \%)$ while in bacterial keratitis, pain $(75 \%)$, redness $(87.5 \%)$, lacrimation $(62.5 \%)$ and hypopyon $(37.5 \%)$ were noted (Table 5$)$.

Scarring of the cornea developing as a result of suppurative corneal ulcer is the second noteworthy reason of preventable blindness after un-operated cataract among people in
Asia, Africa and Middle East. The rate of culture positivity in the present study was $43.3 \%$ while findings of researchers from different parts of the India showed variation (Basak et al., 2005; Bharathi et al., 2002 and Assudani et al., 2013). It may be due to diversity in environmental conditions, occupation and socioeconomic factors which varies from region to region.

Monomicrobial infection was seen in majority (91.04\%) of the cases the most common being fungal $(60.91 \%)$. In mark contrast high prevalence of bacterial isolates was reported by Upadhyay et al., (1991) and Gopinathan et al., (2009). Higher incidence of fungal corneal ulcer in the present study may be due to hot and humid climate of this region.

Table.1 Species wise distribution of fungal isolates

\begin{tabular}{|c|c|c|}
\hline Fungal Species & No. of isolates & Percentage \% \\
\hline Aspergillus flavus & 15 & 28.30 \\
\hline Aspergillus fumigates & 5 & 9.44 \\
\hline Aspergillus niger & 3 & 5.66 \\
\hline Fusarium solani & 6 & 11.32 \\
\hline Candida albicans & 6 & 11.32 \\
\hline Curvularia geniculata & 6 & 11.32 \\
\hline Helminthosporidium & 3 & 5.66 \\
\hline Mucor species & 3 & 5.66 \\
\hline Pseudallescheria boydii & 3 & 5.66 \\
\hline Drechslera species & 3 & 5.66 \\
\hline Total & 53 & 100 \\
\hline
\end{tabular}

Table.2 Frequency of infectious agents with predisposing factors

\begin{tabular}{|l|l|l|l|l|}
\hline & Total & $\begin{array}{l}\text { Fungal } \\
(\boldsymbol{\%})\end{array}$ & $\begin{array}{l}\text { Bacterial } \\
(\mathbf{\%})\end{array}$ & $\begin{array}{l}\text { Mixed } \\
(\boldsymbol{\%})\end{array}$ \\
\hline Ocular trauma & 54 & $44(81.48 \%)$ & $7(12.9 \%)$ & $3(5.55 \%)$ \\
\hline Diabetes Mellitus & 8 & $4(50 \%)$ & $4(50 \%)$ & 0 \\
\hline Acute and Chronic Conjuctivitis & 3 & 0 & $3(100 \%)$ & 0 \\
\hline Contact Lens Wear & 6 & 0 & $6(100 \%)$ & 0 \\
\hline Topical Steroids & 16 & $7(43.7 \%)$ & $7(43.7 \%)$ & $2(12.5 \%)$ \\
\hline Total & 87 & $55(63.21 \%)$ & $27(31.03 \%)$ & $5(5.74 \%)$ \\
\hline
\end{tabular}


Table.3 Association among basis of trauma, cause of trauma and infectious agents

\begin{tabular}{|l|l|l|l|l|l|}
\hline $\begin{array}{l}\text { Basis of } \\
\text { trauma }\end{array}$ & $\begin{array}{l}\text { Cause } \\
\text { trauma }\end{array}$ & No of cases & $\begin{array}{l}\text { Bacterial } \\
\text { cases }\end{array}$ & $\begin{array}{l}\text { Fungal } \\
\text { cases }\end{array}$ & $\begin{array}{l}\text { Mixed infection } \\
\text { cases }\end{array}$ \\
\hline \multirow{2}{*}{$\begin{array}{l}\text { Vegetative } \\
\text { origin }\end{array}$} & Sugarcane leaf & $21(52.5 \%)$ & - & $5(23.8 \%)$ & $3(14.28 \%)$ \\
\cline { 2 - 6 } & Paddy leaf & $12(30 \%)$ & - & $12(100 \%)$ & - \\
\cline { 2 - 6 } & Grass stick & $3(7.5 \%)$ & - & $3(100 \%)$ & - \\
\cline { 2 - 6 } & Thorn prick & $4(10 \%)$ & - & $4(100 \%)$ & - \\
\hline \multicolumn{2}{|c|}{ Total } & $\mathbf{4 0 ( 7 4 . 0 7 \% )}$ & & $\mathbf{3 7 ( 9 1 . 6 \% )}$ & $\mathbf{3 ( 1 4 . 2 8 \% )}$ \\
\hline \multirow{2}{*}{$\begin{array}{l}\text { Foreign } \\
\text { body }\end{array}$} & Wood chip & $7(50 \%)$ & $5(71.4 \%)$ & $2(28.5 \%)$ & - \\
\cline { 2 - 6 } & Iron piece & $2(25 \%)$ & $2(100 \%)$ & - & - \\
\cline { 2 - 6 } & Stone & $5(25 \%)$ & - & $5(100 \%)$ & - \\
\hline Total & $\mathbf{1 4}(\mathbf{2 5 . 9 2 \% )}$ & $\mathbf{7 ( 5 0 \% )}$ & $\mathbf{7 ( 5 0 \% )}$ & \\
\hline Grand Total & $\mathbf{5 4}$ & $\mathbf{7}$ & $\mathbf{4 4}$ & $\mathbf{3}$ \\
\hline
\end{tabular}

Table.4 Demographic profile of patients

\begin{tabular}{|l|l|l|}
\hline Demographics & Particulars & Number of positive patients (\%) \\
\hline \multirow{5}{*}{ Gender } & Male & $113(56.5 \%)$ \\
\cline { 2 - 3 } Age in yrs & Female & $87(43.5 \%)$ \\
\hline \multirow{4}{*}{ Residential Status } & $<20$ & $07(3.5 \%)$ \\
\cline { 2 - 3 } & $20-40$ & $103(51.5 \%)$ \\
\cline { 2 - 3 } & $40-60$ & $63(31.5 \%)$ \\
\cline { 2 - 3 } & $>60$ & $27(13.5 \%)$ \\
\cline { 2 - 3 } & Rural & $117(58.5 \%)$ \\
\cline { 2 - 3 } & Urban & $83(41.5 \%)$ \\
\cline { 2 - 3 } & Farmer & $80(40 \%)$ \\
\cline { 2 - 3 } & Carpenter & $20(10 \%)$ \\
\cline { 2 - 3 } & Gardner & $17(8.5 \%)$ \\
\cline { 2 - 3 } & Labourer & $27(13.5 \%)$ \\
\cline { 2 - 3 } & Student & $10(5 \%)$ \\
\cline { 2 - 3 } & Housewife & $46(23 \%)$ \\
\hline \multirow{5}{*}{ Seasonal variation } & Jan- March & $14(7 \%)$ \\
\cline { 2 - 3 } & April- June & $47(23.5 \%)$ \\
\cline { 2 - 3 } & July- Sep & $77(38.5 \%)$ \\
\hline & Oct- Dec & $62(31 \%)$ \\
\hline
\end{tabular}

Table.5 Clinical features in corneal ulcer $(\mathrm{N}=\mathrm{No}$ of culture positive cases)

\begin{tabular}{|l|l|l|}
\hline Clinical Features & Fungal keratitis N=53 & Bacterial keratitis N=27 \\
\hline SYMPTOMS & & \\
\hline Redness & $43 / 53(81.13 \%)$ & $7 / 27(87.5 \%)$ \\
\hline Pain & $36 / 53(67.9 \%)$ & $6 / 27(75 \%)$ \\
\hline Lacrimation & $09 / 53(56.3 \%)$ & $5 / 27(62.5 \%)$ \\
\hline Photophobia & $07 / 53(43.7 \%)$ & $3 / 27(37.5 \%)$ \\
\hline Blurred/Diminished vision & $43 / 53(81.13 \%)$ & $6 / 27(75 \%)$ \\
\hline SIGNS & & \\
\hline Lid oedema & $05 / 53(31.2 \%)$ & $5 / 27(62.5 \%)$ \\
\hline Hypopyon & $03 / 53(18.7 \%)$ & $3 / 27(37.5 \%)$ \\
\hline Conjunctival congestion & $05 / 53(31.2 \%)$ & $3 / 2737.5 \%)$ \\
\hline Irregular feathery margins & $12 / 53(75 \%)$ & $4 / 27(50 \%)$ \\
\hline
\end{tabular}


Fig.1 Correlation of predisposing factors with culture positivity

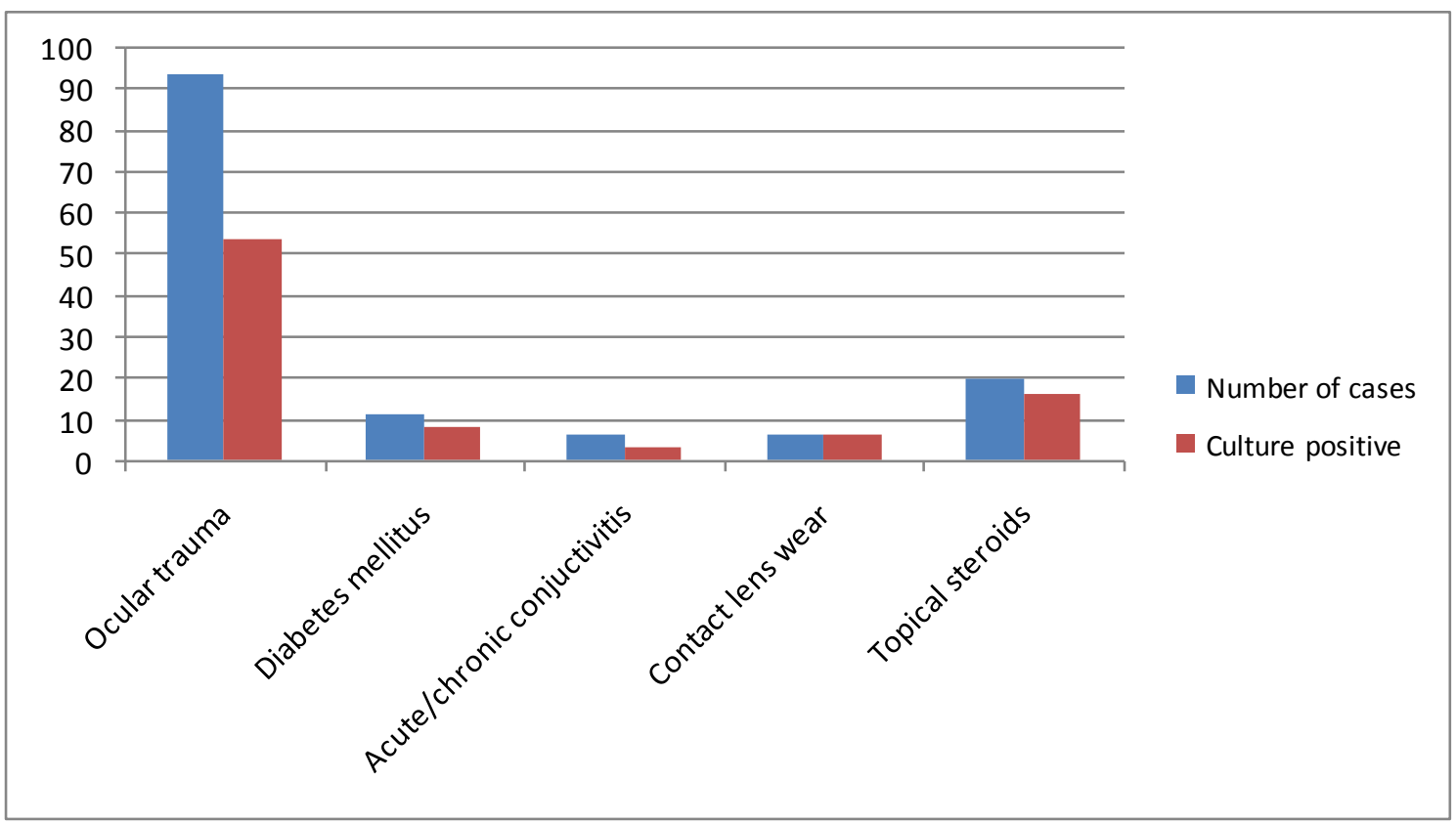

Staphylococcus aureus (68.75\%) was the predominant isolate among the Gram positive bacterial. This observation is comparable to studies by Kaliamurthy et al., (2013) (64.5\%) and Tiwari et al., (2012) (60\%). Staphylococcus aureus and S. epidermidis form the commensal of extraocular surfaces $\&$ invade corneal tissues when compromised by antimicrobial and/or corticosteroid therapy or trauma.

The present study revealed Pseudomonas aeruginosa $(54.54 \%)$ as the most isolated organism among the Gram negative bacterial causes which is in accordance with that reported by Sirikul et al., (2008) and Keshav et al., (2008).

Aspergillus species (43.39\%) was the most prevalent pathogen in the present study as the cause of fungal keratitis. This was comparable to Chander J et al., (1993) and Kaur P et al., (2011) which showed Aspergillus spp. as the most common isolate with $41.8 \%$ and $50 \%$ respectively. Predominance of Aspergillus species may be explained by differences in climate and the natural environment. Moulds with enteroblastic conidia adhering in dry chains as in Aspergillus spp. were more frequently isolated from patients in the north of the country where the environment usually drier and dustier, than in more humid south. Also the spores of Aspergillus spp. can tolerate hot, dry weather conditions.

Haryana being an agriculture land, farming induced trauma is very common. Corneal trauma was the most frequent predisposing factor of suppurative corneal ulcer in the present study $(52.5 \%)$ unlike results of Western countries where contact lens wear was the chief predisposing factor as seen by Frederic et al., (2001) and Sirikul et al., (2008). Low occurrence of Contact lensinduced corneal ulcers in this study may be due to the fact that the majority of the patients were from rural background where use of contact lens is rare. The fungal etiology $(81.48 \%)$ was most commonly associated with ocular trauma in the present study. The reason behind it may be, as fungi are soil saprophytes and plant pathogens as a result 
linked to agricultural workers. Furthermore Indian climate favors the growth of these fungi.

Frequency of ocular trauma due to vegetative origin was predominant $(74.07 \%)$ than foreign body. Fungal keratitis was mainly caused by trauma due to vegetable origin $(91.06 \%)$ and sugarcane leaf accounted for $23.8 \%$ of the cases. This is in accordance with Chander et al., (1993) and Sanjeev $\mathrm{H}$ et al., (2012). Injury with sugarcane leaf predominates as it is the principal agricultural product in this region and the height of sugarcane plant reaches the average level of the human eye.

Studying the demographic profile, corneal ulceration was higher in males and in age group 20-40 years as observed by Hagan et al., (1995) and Bashir et al., (2005). Male predominance may be because they are physically more active and mostly involved in outdoor activities therefore much more vulnerable to trauma. The seasonal variation showed a rise in number of cases in hot, humid season of July-Sep (38.33\%). A large number of cases of keratitis in the months of Oct-Dec $(31 \%)$ were also seen which the harvesting season of sugarcane is.

In bacterial corneal ulcers, toxins produced by the bacteria diffuse through the cornea into the anterior chamber exerting an irritative effect. Pain occurs due to the exposure of the terminal fibres of the ophthalmic division of the trigeminal nerve. In the present study, pain $(87.5 \%)$, redness $(87.5 \%)$, lacrimation $(62.5 \%)$, hypopyon $(37.5 \%)$ was the main clinical feature noted in bacterial keratitis. Fungal ulcers are characterized by a relatively indolent course. Symptoms are much milder than the signs. The hypopyon is thick and immobile, and it is due to invasion into the anterior chamber of fungal hyphae enmeshed in thick exudates. In the present study, the prime clinical features observed in fungal keratitis were redness $(81.25 \%)$, blurred/diminished vision $(81.25 \%)$, pain $(68.7 \%)$ and irregular feathery margins $(75 \%)$. It clearly shows that the clinical features do not always correlate with the textbook description. Certain clinical characteristics of corneal ulcers may suggest a specific pathogen, but a reliable diagnosis cannot be made by clinical appearance alone.

To conclude, corneal ulcer is an avoidable vision-threatening disease that still represents a considerable proportion of the daily new cases that creates a huge burden on the resources of health services. The clinical presentations of bacterial and fungal corneal ulcers are often overlapping. The definitive diagnosis of ulcers caused by multiple organisms can only be arrived at by microbiological evaluation. Accurate diagnostic tests not only play a key role in patient management but also reduce the risk of the patient developing long-term complications.

\section{References}

Assudani, J.H., Pandya, J.M., Sarvan, R.R., Sapre, A.M., Gupta, A.R., Mehta, S.J. 2013. Etiological diagnosis of microbial keratitis in a tertiary care hospital in Gujarat, National Journal of Medical Research. 3(1): 60-2.

Balagurunathan, R., Shanthi, J., Vanaja priya, R. 2012. Laboratory diagnosis and prevalence study of corneal infections from a tertiary eye care hospital. Adv. Appl. Sci. Res. 3(3): 1598-1602.

Basak, S.K., Basak, S., Mohanta, A., Bhowmick, A. 2005. Epidemiological and microbiological diagnosis of suppurative keratitis in Gangatic West Bengal, Eastern India. Indian $\mathbf{J}$ Ophthalmol. 53(1): 17-22.

Bashir, G., Shah, A., Thokar, M.A., Rashid, S., Shakeel, S. 2005. Bacterial and fungal 
profile of corneal ulcers-a prospective study. Indian Jour. Of Pathology and Microbiology. 48(2): 273-77.

Bharathi, M.J., Ramakrishnan, R., Vasu, S., Meenakshi Palaniappan, R. 2002. Aetiological diagnosis of microbial keratitis in South India - A study of 1618 cases. Indian J Med Microbiol. 20(1): 1924.

Chander, J., Chakrabart, A., Sharma A. 1993. Evaluation of calcofluor staining in the diagnosis of fungal corneal ulcer. Mycoses. 36(1): 243-45.

Frederic, Schaefer, Olivier, Bruttin, Léonidas, Zografos. 2001. Bacterial keratitis: a prospective clinical and microbiological study. British journal of ophthalmology. 85(1): 842-47.

Geethakumari, P.V., Remya, R., Girijadevi, M.S., Reena, A. 2011. Bacterial Keratitis and Fungal Keratitis in South Kerala: A Comparative Study. KJO. 23(1): 43-46.

Gopinathan, U., Sharma, S., Garg, P., Rao, G.N. 2009. Review of epidemiological features, microbial diagnosis and treatment outcome of microbial keratitis: Experience of over a decade. Indian $\mathbf{J}$ Ophthalmol. 57(2): 273-79.

Hagan, M., Wright, E., Newman, M., et al., 1995. Causes of suppurative keratitis in Ghana. Br J Ophthalmol. 79(1): 1024-8.

Kaliamurthy, J., Kalavathy, C.M., Parmar, P., Jesudasan, C.A., Thomas, P.A. 2013. Spectrum of bacterial keratitis at a tertiary eye care centre in India. BioMed Research International. 3(2): 112-20.

Kaur, P., Devi, P. 2011. Keratomycosis-A retrospective study from North Indian tertiary care institute. JIACM. 12(4): 27173.
Keshav, B.R., Zacheria, G., Ideculla, T., Bhat, V., Joseph M. 2008. Epidemiological Characteristics of Corneal ulcers in south sharqiya Region. Oman Medical Journal. 23(1): 82-8.

Sanjeev, H., Karnaker Vimal, K., Pai, Vijay, Pai Asha, K.B., Rai, Rekha, Krishnaprasad, M.S. 2012. Fungal Profile of infectious keratitis in a tertiary care hospital- our experience. NUJHS. 2(2): 10-14.

Sirikul, T., Prabriputaloong, T., Smathivat, A., Chuck, R.S., Vongthongsri, A. 2008. Predisposing Factors and Etiologic Diagnosis of Ulcerative Keratitis. Cornea. 27(3): 283-87.

Srinivasan, M., Gonzales, C.A., George, C, et al., 1997. Epidemiology and etiological diagnoses of corneal ulceration in Madurai, South India. Br J Ophthalmol. 81(2): 965-71.

Tewari, A., Sood, N., Vegad, M.M., Mehta, D.C. 2012. Epidemiological and microbiological profile of infective keratitis in Ahmedabad. Indian $\mathbf{J}$ Ophthalmol. 60(2): 267-72.

Upadhyay, M.P., Karmacharya, P.C., Koirala, S., Tuladhar, N., Bryan, L.E., Smolin G, et al., 1991. Epidemiologic characteristics, predisposing factors and etiologic diagnosis of corneal ulceration in Nepal. Am J Ophthalmol. 111(2): 9299.

Wilson, L.A., Ajello L. Agents of oculomycosis. Fungal infections of the eye. L Collier, A Balows and A Sussman, editors. Topley and Wilson's microbiology and microbial Infections. $9^{\text {th }}$ ed. Vol. 4. London, England: Arnold. 1998. p. 525-44.

\section{How to cite this article:}

Kanishtha Sharma, Dipender Kaur Najotra and Varsha A. Singh. 2017. Clinico-Epidemological Profile of Corneal Ulcer Cases from Rural Hospital of Haryana, India. Int.J.Curr.Microbiol.App.Sci. 6(9): 2410-2416. doi: https://doi.org/10.20546/ijcmas.2017.609.296 